\title{
THEORY OF KNOWLEDGE AND THEORY OF SCIENCE IN THE WORK OF AUGUSTE COMTE Note on Comte's ORIginality
}

\begin{abstract}
"Au lieu de chercher aveuglément une stérile unité scientifique, aussi oppressive que chimérique, dans la vicieuse réduction de tous les phénomènes à un seul ordre de lois, l'esprit humain regardera finalement les diverses classes d'événements comme ayant leurs lois spéciales."
\end{abstract}

Auguste Comte.

RÉSUMÉ. - Théorie de la connaissance et théorie des sciences chez Auguste Comte.

Plutôt que de réduire l'auvre de Comte à son "positivisme", il est utile d'établir une distinction entre sa théorie de la connaissance et sa théorie des sciences. Si la théorie de la connaissance comtienne ne paraît pas particulièrement originale, sa théorie des sciences est ici considérée comme une innovation intellectuelle majeure : c'est une des toutes premières théories historiques et différentielles. Elle a été capitale pour la formation de l'épistémologie française.

The most common opinion on the work of Auguste Comte is that it can well be reduced to the issue of " positivism ". Comments generally indicate that the sense of his writings may be recapitulated by this word, however trivial and however abominable the matter is considered today. Ever since the unfortunate polytechnicien presented his enterprise under the sign of « positive philosophy ", his disciples and critics alike have associated his name with the "positivist " doctrine. And especially in the social sciences, nothing is more evident than that Comte's intellectual significance resides in his positivism in all its manifestations (from his epistemology and sociology to the religion of humanity) ${ }^{1}$.

1. For a typical example see the introduction by Gertrud Lenzer, in Auguste Comte and Positivism. The Essential Writings, ed. by Gertrud Lenzer, Chicago, Chicago University Press, 1975. See also Anthony Giddens, ed., Positivism and Sociology, London, Heinemann, 1974; Christopher Bryant, Positivism in Social Theory and Research, New York, St Martin's Press,

Revue de synthèse: IV S. $\mathrm{N}^{\circ} 1$, janv.-mars 1991. 
In this essay ${ }^{2}$, I would like to raise two questions as to this dominant image. First of all, does this " positivism " represent historically such an original conception? Historians of science seem to conclude that it was less original than philosophers tend to assume. Once Comte is situated in the history of the sciences, his notions appear to be less new and less scandalous than in traditional histories of philosophy. The characteristics Comte attributed to positive knowledge largely corresponded to the conceptions of the "newtonian current" in French science, including both mathematical physicists and representatives of the life sciences such as Barthez ${ }^{3}$. From this perspective, Comte's originality seems to have been overemphasized. If this is true, either Comte was not a very original thinker or his originality resides elsewhere. It is useful in this connection to distinguish his theory of knowledge from his theory of the sciences. This distinction is somewhat obscured by the term "epistemology", since it can mean both. Positivism in Comte's work was first and foremost a theory of knowledge. It was founded on his scheme of the "three stages ", which was founded in turn on a conception of the human mind. His theory of the sciences, however, was less general and far more specific, founded as it was on the idea of the "hierarchy of the sciences " ${ }^{4}$. Broadly speaking, his theory of knowledge was concerned with the common characteristics of knowledge : the progressive break with theology and metaphysics, and the development towards positive forms of cognition, involving his notions of "laws" and "explanation". The theory of the sciences, on the other hand, was concerned with the specific properties of the various sciences. What I would like to suggest here is that this theory of knowledge was not particularly original, whereas his theory of the sciences represents an important innovation of great historical significance.

1985 ; Theodor W. Adonno, et al., Der Positivismusstreit in der deutschen Soziologie, Darmstadt, Luchterhand, 1972.

2. This text was presented in $\mathbf{1 9 8 9}$ in a seminar of the Swedish Collegium for Advanced Study in the Social Sciences in Uppsala, Sweden. It is based on the last part of my Het ontstaan van de sociologie (The Making of Sociology), Amsterdam, Prometheus, 1990, p. 207 281 .

3. See especially the different studies of Georges Canguilhem; Gaston BACHELARD, Etude sur l'évolution d'un problème de physique. La propagation thermique dans les solides, Paris, Vrin, 1928, p. 33-72; Léon BRUNSCHVICG, L'Expérience humaine et la causalité physique, Paris, Presses universitaires de France, 1949, p. 324-330; Georg Misch, Zur Entstehung des französischen Positivismus, Darmstadt, Wissenschaftliche Buchgesellschaft, 1969.

4. A summary of his theory of knowledge can be found in the first lesson of the Cours de philosophie positive, and an outline of his theory of science is presented in the second lesson. 
SENSES OF POSITIVISM

Ordinarily the notion of "positivism " is used in two senses. First, it denotes an imitation of the natural sciences in the domain of the human sciences. Hobbes is thus probably the first "positivist", Condorcet, Cabanis and perhaps the early Saint-Simon were positivists, but Comte rejected such imitations and was not a positivist in this sense. As early as 1819, Comte noted :

« Les erreurs de [...] Condorcet, Cabanis et M. de Tracy proviennent toutes de cette idée fausse qu'il n'y a d'autre moyen de rendre positive la science sociale que de la fonder sur une autre science, déjà positive elle-même " ${ }^{5}$.

Positivism can also refer more broadly to antimetaphysical conceptions of knowledge. Here the central idea is that no positive knowledge can be acquired of "first and final causes " or of the " essence " of phenomena, and that all such questions have to be banned from science. Comte was of course a positivist in this sense, but it is not certain that he contributed much to the formulation of this conception. He invented a word for it, but did he actually do much more? Positivism in this sense emerged parallel to classical physics. Newton wished to refrain from « hypothetical questions ", i.e. questions about first or final causes. This attitude became prevalent at the French Academy of Sciences during the eighteenth century $^{6}$, and the rejection of metaphysics was commonly accepted in French scientific circles around $1800^{7}$.

Comte never disputed this development. On the contrary, he stressed that positivism in this sense was nothing new. In 1835, he addressed the Academy of Sciences and started his speech by saying that scientific statements need "positive verification". This "general principle" was an « indispensable condition" for validity and was « universally accepted ${ }^{8}$. He expressed the same attitude in the Cours de philosophie positive :

5. Auguste Сомте, Écrits de jeunesse, 1816-1828, Paris, Mouton, 1970, p. 418.

6. Roger HaHN, The Paris Academy of Sciences, 1666-1803, Berkeley, University of California Press, 1971, p. 34.

7. Nicole Dhombres, Jean Dhombres, Naissance d'un nouveau pouvoir : sciences et savants en France (1793-1824), Paris, Payot, 1989, p. 450.

8. A. Comte, « Premier mémoire sur la cosmogonie positive » (1835), in op. cit. supra n. 5, p. 585. 
" Il est inutile d'insister beaucoup sur un principe devenu maintenant aussi familier à tous ceux qui ont fait une étude un peu approfondie des sciences d'observation " '.

In his first writings, Comte made no claim to have contributed much to the idea of " positive science ". He viewed his law of the three stages as a great discovery, but made no attempt to formulate new or particularly strict criteria for what positive science was or was not. In a sense, he delegated the question of " demarcation " to the various sciences. It was only in his later works, written after his second crisis in 1838, that his " positivism " became a more elaborate system. "Positive " then no longer meant " real " and " testable " but also " useful ", " precise " and " certain " 10 . This change coincided with a marked disinterest in scientific practices and an increased suspicion of scientists.

If Comte made any contribution to a theory of positive knowledge, it is probably by generalizing conceptions that already existed in the sciences of his time. One might therefore doubt whether these aspects of his work can be interpreted as important innovations. And historically, these contributions have not been especially significant either. For the logical positivists Comte barely existed; there is not one such thinker for whom Comte was important. In fact, Comte's theory was opposed in many ways to the program of the logical positivists. Comte rejected the idea that there existed purely logical criteria or universal methods by which scientific statements could be distinguished once and for all from nonscientific ones. His positivism was historical, not logical, and according to him there was no "positive method", independent of the practices of the various sciences ${ }^{11}$.

9. ID., Philosophie première. Cours de philosophie positive, leçons 1 à 45. Présentation et notes par Michel Serres, François Dagognet et Allal Sinaceur, Paris, Hermann, 1975, p. 26. It is curious that this edition, presented as "la première édition savante ", has no index and does not contain the "avertissement " where Comte discusses his notion of positive philosophy.

10. See, for example, А. ComTE, Discours sur l'esprit positif, 1844, Paris, Vrin, 1983, p. 64-65.

11. See, for example, his statement in the first lesson of the Cours : "La méthode n'est pas susceptible d'être étudiée séparément des recherches où elle est employée; ou, du moins, ce n'est là qu'une étude morte, incapable de féconder l'esprit qui s'y livre. ". 
COMTE'S ORIGINALITY

The mistake of many interpretations is that they reduce Comte's theory of the sciences to his theory of knowledge. His theory of science, in other words, is presented as merely a specification of his positivist methodo$\operatorname{logy}{ }^{12}$. But this image is in many ways misleading. Although his conception of positive knowledge was not very original, one might say that Comte was one of the very first to elaborate a historical and differential theory of science. Comte, in effect, broke with the idea that science could be founded on some nonhistorical, logical or universal principle. $\mathrm{He}$ accordingly rejected virtually all the existing theories. Descartes had located a foundation for knowledge in an ahistorical thinking subject; Leibniz had searched for a logical foundation and unification of science; all the classical theories presupposed a timeless and universal criterion for truth ${ }^{13}$.

Comte broke with this presupposition as the result of a twofold operation. First, Comte historized the question : scientific knowledge was a historical process. Concepts and theories change; any statement about science should therefore be a statement about historical processes. In comparison with Turgot and Condorcet, and with German historicism and Hegelian philosophy, this position was not uncommon. More original was the second operation, whereby Comte differentiated the sciences according to the specific characteristics of their object. He opposed monist and reductionist theories of science and replaced them with a differential theory. What science was did not only depend on phases and stages, but also on the specific properties of the scientific object in question. It was impossible to reduce the different sciences to one basic type.

This differential approach was in part the result of an observation. With the expansion and the unprecedented prestige of science in the revolutionary period in France, scientific differentiation accelerated. The Academy of Sciences remained a dominant institution, but was no longer the undisputed center of scientific work. Under the Old Regime the Academy of

12. According to Giddens, for example, positivism implies « that the methodological procedures of natural science may be directly adapted to sociology", see A. GIDDENS, "Introduction ", in ID., ed., Positivism and Sociology, London, Heinemann, 1974, p. 3.

13. See, for example, R McRaE, The Problem of the Unity of the Sciences : Bacon to Kant, Toronto, Toronto University Press, 1961; Edward KenNEDY, " Destutt de Tracy and the Unity of the Sciences ", Studies on Voltaire and the Eighteenth Century, 171, 1977, p. 223239. 
Sciences, like other academies, had a monopoly of judgement. A scientist's career depended essentially on whether he had the Academy's support and it also controlled the opportunities for publication. One of the major effects of the French Revolution was that the monopolistic structures of professional corporations were abolished. Academic societies were replaced by a network of various institutions : grandes écoles like the École polytechnique, the Institut de France, the faculties of the Napoleonic university, the new Bureau des longitudes, and so forth. For the first time specialized journals and more or less disciplinary scientific societies came to play a major role in science. At the same time conflicts became apparent among what would soon be "disciplines " in the modern sense.

The new intellectual regime, to borrow one of Comte's terms, was a more differentiated structure in which the traditional « supra-disciplinary control $\gg{ }^{14}$ was severely weakened. This shift can be described as the transition of the classical to the modern epistemic regime. It was accompanied by a similar change in epistemology. Whereas during the Enlightenment, theories of science had been based on the unity and invariability of reason, around 1800 epistemology became an arena for competing conceptions and cognitive strategies.

In France this change led to open conflict, especially between representatives of the mathematico-mechanical disciplines and spokesmen of the life sciences. Each group tended to defend a form of monism. Representatives of the mathematical sciences, such as Condorcet and Laplace, claimed their models were also valid for chemistry, biology and even the " moral sciences". With the calculus and probability theory, mathematization had become an important tool in many areas. Condorcet's « social mathematics " was only one example of this trend. Some representatives of the life sciences, on the other hand, argued that their theories were in fact more general. Cabanis, for example, claimed that gravity was merely a particular form of "affinity " or "sensibility", and that physics was therefore part of the more general science of physiology ${ }^{15}$.

Against this background, Auguste Comte can be seen as one of the first to investigate these struggles with some measure of detachment. He rejected the generalizations of the various parties and tried to specify under which conditions certain methods and procedures were more effective than others. The result was a differential theory of science, founded on the distinction between various levels of complexity. Astronomers studied the geometry and the mechanics of celestial bodies; these were fairly simple

14. R. STісншен, Zur Entstehung des modernen Systems wissenschaftlicher Disziplinen. Physik in Deutschland 1740-1890, Frankfurt am Main, Suhrkamp, 1984.

15. Martin S. Staum, Cabanis. Enlightenment and Medical Philosophy in the French Revolution, Princeton, Princeton University Press, 1980, p. 179-182. 
phenomena. Physics was a more complex and less unified field, which could not be reduced to geometry and mechanics. Physical phenomena (light, heat, electricity, magnetism), however, were simple enough for mathematical description. Chemists studied matter at the level of molecular " composition " and « decomposition ". These processes were not only subject to the laws of mechanics and physics, but more specifically to « chemical affinities". Biologists studied living beings, which were more complex than dead bodies. Their conduct could not be solely explained by physical forces and chemical affinities, since it primarily depended on the " organization" of the body. Social phenomena were even more complicated because human beings had the capacity to learn. In that respect, they differed from other living creatures.

The sciences, Comte argued, constituted a series of increasing complexity and decreasing generality. The laws of mechanics and physics were fairly simple and were valid for all natural phenomena, large or small, dead or alive. Chemistry was more complex and less general. There were many physical phenomena with no chemical effect, but no chemical phenomena without physical effects. The laws of biology were more complex, and were only valid for living bodies. The laws of human societies were still more complex and less general. Human beings represented, so to speak, the smallest subset of natural phenomena.

This series of increasing complexities, according to Comte, also explained the historical development of the sciences. The human mind first discovered the principles of the simplest objects. Knowledge of more complex objects was acquired only after the simpler phenomena had become known. Chemistry did not become a positive science until the 18 th century. Biology was in the process of becoming one; in sociology the first steps had yet to be taken.

This idea of a differential series of the sciences, based on the cognitive heterogeneity of their objects, was elaborated in detail in the Cours de philosophie positive (1830-1842). Comte's theory basically concerned relationships between the different sciences. He recognized, of course, that the sciences had characteristics in common, and discussed this in the first lesson of the Cours. There one finds Comte's positivist theory of knowledge. But the six volumes of the Cours were not about what the sciences had in common. Contrary to what is often assumed, they were not primarily concerned with the "demarcation» between science and metaphysics. The Cours addressed the question of how recent developments in the sciences could be interpreted in view of his scheme of " increasing complexity" and "decreasing generality". Thus the Cours de philosophie positive is not primarily a positivist textbook, and positivism (in the sense of an antimetaphysical conception of knowledge) was not its princi- 
pal subject. It is more accurate to say that the Cours is essentially an elaboration of a historical and differential theory of the sciences.

If this interpretation is valid, Auguste Comte can be described as one of the very first modern theorists of science. His differential approach to scientific knowledge implied a rejection of any claim for scientific monopolies. It also put an end to the illusion of universal methods. This antireductionist mode of theorizing was an important intellectual breakthrough. Thus what needs explaining is not so much Comte's more general theory of knowledge but his theory of the sciences.

THE DYNAMICS OF THE COMTEAN PROJECT

Comte grew up in a period when French science was flourishing as never before. Around 1800 Paris became the center of the scientific world. This pertained to almost every field, especially the mathematical disciplines. At school Comte had been most impressed by his mathematics teacher, and at the age of fourteen he began to prepare for the entrance examinations of the École polytechnique. In 1814 seventy-five candidates were admitted to the prestigious school. Comte entered in forth place; three Parisians had done better ${ }^{16}$. Comte left his home town Montpellier; after a journey of sixteen days he arrived in Paris to start his studies. His teachers included some of the best known scientists of the day, and his first letters to friends show enormous enthusiasm and excitement.

Barely two years later a crucial event was to change Comte's life in an unexpected manner. The École polytechnique was closed down, and the pupils were sent home. A conflict between the students and an authoritarian and royalist tutor had set off a student rebellion. In the midst of this conflict fifteen pupils asked the man to leave the school; one of them was Auguste Comte. The directors of the school felt it was necessary to demonstrate firmness, because they needed the support of the Restoration government. They demanded that the government expel the fifteen pupils. The government, in turn, closed down the entire school, which was suspected of republicanism and Napoleonic sympathies.

Comte was forced to return to Montpellier. He took courses at the Faculty of Medicine, but Paris soon proved irresistible. He went back to

16. For the biography of Comte, see Henri GouHIER, La Jeunesse d'Auguste Comte et la formation du positivisme, Paris, Vrin, 1933-1941, 3 vols, and La Vie d'Auguste Comte, Paris, Gallimard, 1931. 
the capital, and from that time on earned his living by giving private lessons in mathematics. Occasionally he considered finding a more decent job. He was paid by Saint-Simon for some months; he had a plan to go to England; he dreamed about a chair ; but for sixteen years he continued his lessons. It was not until after the Revolution of July 1830 that he began to tutor at the École polytechnique. By then, however, his theory had already been formulated ; all it needed was elaboration and recognition.

A closer look at these years makes it possible to reconstruct the steps that led to his theory. The first systematic outline was found in a book published in 1822, thus the idea had emerged in the six previous years. In this period Comte struggled with two problems, both linked to his exclusion from the École polytechnique.

The first problem was political. Comte blamed the Bourbon Restoration for his expulsion. His very first text was a violent attack on the " terrible league of kings and priests ". Almost immediately afterwards, however, Comte raised the question of a more scientific approach to politics and society. In his early articles he clearly drew on Saint-Simonian arguments, but his work differed in tone and style from the prophetic declarations of his master. His views corresponded to those of the liberal opposition, but were not merely political comments. He wrote a text on tax reform which is actually an analysis of the function of taxes in industrial society. He also wrote a critical note about the role of liberal politicians stating that it is not possible to analyze and participate in politics at the same time. Thus even these early political texts reveal the dispositions of a scientist, or in any case of someone used to reasoning in a way that was very different from Saint-Simon's.

The second problem Comte addressed was mathematics, which was the basis of the curriculum at the École polytechnique. Many of the leading scientists in France were mathematicians, and they had been either teachers or pupils at the school. Their reputation was largely based upon what has been described as the "burst of mathematization " in the first quarter of the 19 th century ${ }^{17}$. French scientists firmly dominated this development of which Laplace was the leading proponent ${ }^{18}$. Mathematics was also the science Comte knew best. He did not doubt its significance,

17. Thomas KuHN, " Mathematical vs. Experimental Traditions in the Development of Physical Science ", Journal of Interdisciplinary History, 7, 1976, p. 1-31.

18. Robert Fox, "The Rise and Fall of Laplacian Physics ", Historical Studies in the Development of the Physical Sciences, 4, 1974, p. 89-136; I. Grattan-Guinness, " Mathematical Physics in France, 1800-1840 : Knowledge, Activity and Historiography ", in J. W. DAUBEN, ed., Mathematical Perspectives. Essays on Mathematics and its Historical Development, New York, Academic Press, 1981, p. 95-135. 
but became increasingly critical about how mathematical tools were used. He was also critical about the unlimited claims made in the name of mathematics. What was needed, he thought, was a theory of mathematics that would also account for its limitations. Such a theory would be useful to scientists and teachers of mathematics alike. Liberated from the routines of the school, Comte felt he perceived the imperfections of its mathematical spirit more clearly than others. The book he planned on the subject, however, was never written. He abandoned it after about eighty pages because he discovered that a theory of mathematics would have to be based on the role of mathematics in science, and an explanation of this role would require a theory of science rather than a theory of mathematics.

In 1819 Comte was convinced he had formulated the problem in a new way and was reaching an interesting solution. The " learning years " were over, he wrote to a friend, and to mark the transition he changed his name from Isidore to Auguste.

In a letter, the 21-years-old Comte explained to a friend that most mathematicians were merely « calculating machines ». They were preoccupied with a few special questions, and did not even understand why the methods they applied were so effective. If they had some knowledge of other sciences and methods, they would understand their own work better and would not claim that all scientific problems had a mathematical solution ${ }^{19}$. Comte had in mind the biomedical sciences. For these disciplines, which were not taught at the Ecole polytechnique, the term « biology " was coined in the years around 1800 . The introduction of a general term to cover botany, zoology, and medicine was part of a struggle for scientific recognition. Lamarck, who had introduced the term in France, opposed the efforts of mathematical physicists in this domain and strongly rejected the validity of their approach ${ }^{20}$. A similar position had been formulated by Bichat, who belonged to the "school " of Montpellier. Comte often referred to Bichat and called him the true founder of bio$\operatorname{logy}$; in the positivist calendar it is Bichat rather than Galilei, Newton or Laplace who figures as the patron of modern science.

The Montpellier version of biology is an important clue to the Comtean theory of the sciences. According to Bichat, living organisms differ from inorganic phenomena in that they are irregular. Therefore in biology it is impossible to look for the same kind of regularities as in

19. A. Сомте, “Lettre à Valat, le 24 septembre 1819 », in Correspondance générale et confessions, Paris, Mouton, 1973, t. 1, p. 51-61.

20. On Lamarck, see Joseph ScHILler, ed., Colloque international Lamarck, Paris, A. Blanchard, 1971; Pietro CorsI, The Age of Lamarck. Evolutionary Theories in France 1790-1830, Berkeley, University of California Press, 1988. 
mechanics. Mathematical models were inappropriate, and biology should be an independent science based on the study of "vital principles " or « vital forces " ${ }^{21}$.

Comte was not an unconditional admirer of this concept. He reformulated certain aspects, but basically agreed with it. With the recognition of biology as a science different from physics, Comte acquired a fruitful analogy to redefine the status of social science. Social science would be to biology what biology was to chemistry. This reasoning can be found almost literally in a note written by Comte in 1819. The note is titled : Considérations sur les tentatives qui ont été faites pour fonder la science sociale sur la physiologie et sur quelques autres sciences ${ }^{22}$.

If the analogy with biology was to be followed, what were the specific characteristics of social phenomena as compared to biological ones? The answer is provided by a text about Condorcet written in the same year. The progressive development of civilization, or the law of progress, is the dominant force in the human world. It was, in a way, the « vital principle " in the life of human beings; according to Comte, it is to Condorcet's credit that he discovered $i^{23}$.

Thus Bichat's concept of biology was the clue to Comte's theory of the sciences. The theory of the sciences, in turn, was the solution to the two problems with which Comte struggled : mathematics and politics. In his theory of science, they form the two ends of the chain.

\section{A CRITIQUE OF MATHEMATICAL REASON}

Comte's theory was the outcome of a dilemma. It was the work of a man thoroughly trained in the mathematical and physical sciences, who had been virtually expelled from the scientific community and excluded from the career possibilities his education normally offered. From the beginning, Comte's intention was critical : he wanted to write a sort of critique of mathematical reason. Yet it was no less typical of his project that this critique was to be constructive. It was to be based on science and addressed to the very people who were the object of his criticism ${ }^{24}$.

21. See especially Georges CANGUILHEM, Études d'histoire et de philosophie des sciences, Paris, Vrin, 1983, p. 75-80.

22. A. COMTE, op. cit. supra n. 5, p. 473-482.

23. ID., "Sur les travaux politiques de Condorcet", 1819, in op. cit. supra n. 5, p. 483489.

24. For an early example, see ID., " Des conditions à remplir pour cultiver la philosophie des mathématiques ", 1819-1820, in op. cit. supra n. 5, p. 495. 
Comte did not recognize any reference group other than these mathematically trained physicists at the Ecole polytechnique and the Academy of Sciences. He made no effort to get a position anywhere else, and maintained that biologists and sociologists should first learn mathematics and physics before starting to work on more complex objects.

Comte tried to convince his former colleagues that they unjustly claimed a monopoly of scientificity. There were other positive sciences, and physicists could learn other procedures in addition to the ones they were accustomed to. From biologists they could learn the comparative method, and from sociologists the historical method. To think there were mathematical methods for these sciences was to strive for «impossible perfection ", as Comte stated in his early texts. His later formulations were less diplomatic. In the Cours he rejected probability theory, because he saw it as an instrument of mathematicians to dominate the other sciences.

On the other hand, Comte did not agree with the biologist's claim to independence. Increasing complexity also meant increasing dependence. Living beings depended on chemical and physical processes, whereas physics and chemistry did not depend on biology. Biological phenomena constituted a specific level of reality, but it was not an independent one. Nor was it an antagonistic level, as Bichat had supposed. The struggle between the forces of life and the forces of death was a vitalist myth Comte did not accept. Instead, he did much to find concepts that could bridge the gap between the organic and the inorganic. His idea was that of "relatively autonomous" sciences. Comte formulated this idea, although he did not use the expression, which seems to be very recent ${ }^{25}$.

It is not possible to state exactly when and how Comte discovered the work of the biologists ${ }^{26}$. Yet he must have assimilated their work, because it was the only critique of mathematical physics that was scientifically sound. There were many other forms of critique, but Comte was never tempted by the antiscientific romanticisms of Chateaubriand and Fontanes. What Saint-Simon wrote about science must have been like science fiction to Comte, and he felt deep contempt for spiritualist philosophers such as Victor Cousin.

25. The first texts in which I found the expression " relatively autonomous " were written by Louis Althusser and Norbert Elias (see Louis Althusser, Étienne Balibar, Lire "le Capital ", 1968, Paris, Maspero, 1975, t. 1, p. 71, 121, 124-125, and Elias' book, Qu'est-ce que la sociologie?, which appeared in German in 1970 and contains a whole chapter on Comte). These two authors are also just about the only ones to have recently expressed their admiration for Comte. For Althusser, see Pour Marx, Paris, Maspero, 1965, p. 16 and Lénine et la philosophie, Paris, Maspero, 1972, p. 11 ; see also Pierre Macherey, Comte. La philosophie et les sciences, Paris, Presses universitaires de France, 1989.

26. According to Gouhier Comte met Blainville shortly after 1822 , but his first references to physiology were well before this date. 
Comte adhered to a strict idea of positive science, and his proposals were addressed to the established scientists. This perseverance is linked to the fact that he had no resources other than his scientific abilities. Since he came from a relatively low social background, he had no economic resources. Being a native of Montpellier, he had very few relations in Paris, and he felt incapable of moving in Parisian circles. In this world he was condemned to "philosophical observations", as he wrote in a letter describing his visit to a ball. He did not dance, and disliked the gens comme il faut. What he had was his scientific capital, and in the beginning his whole strategy was aimed at accumulating this form of capital in a particular way. The Cours de philosophie positive may be seen as the result of this strategy.

Comte's theory emerged from the tensions between a scientist and the scientific establishment from which he was partially excluded. The distance allowed him to see what insiders did not and what outsiders could not see with sufficient precision. By elaborating these insights, he hoped to win back what had been taken from him, and in fact his first work was fairly well received. In 1826 , he made another move and started his course in "positive philosophy ". A few prominent members of the Academy of Sciences attended the opening session. In 1830 the first volume of the Cours appeared in print; by 1838 , however, having reached the forth volume, Comte wrote that there was no longer any hope that his project would gain recognition. Scientists were only interested in their own specializations and careers, and other intellectuals were even worse. For reasons of « mental hygiene ", Comte stopped reading other work. This act symbolized the change in his relationship with the intellectual world. It heralded a new dynamic - a search for a new audience and other possibilities and pleasures.

What Auguste Comte had offered was too critical for the scientific establishment and too scientific for men of letters and philosophers. That is the most important reason why his theory of the sciences was ignored for such a long time.

CONCLUSION

Comte's theory of the sciences was a detailed elaboration of a historical and differential model of science. It was opposed to any form of cognitive absolutism and - however strange it may seem - Comte thought of himself as a relativist. "Tout est relatif, voilà la seule chose absolue " was 
a favorite maxim of the young Comte ${ }^{27}$. For Comte this « relativism » was related to the historical nature of science and to his differential « onto$\operatorname{logy}$ " of the sciences. The theory was formulated in opposition to what he called « intellectual absolutism », but because it presented an " ontological " scheme, it was also opposed to the intellectual voluntarism that spokesmen of the literary intelligentsia propagated. Chateaubriand and later Romantics adhered to the cult of the creative genius. In contrast to such forms of intellectual voluntarism, Comte's theory presented an account of the sciences formulated in terms of the degrees of complexity and generality of their object. Today the issue is whether there is any need or possibility for even such a minimal form of ontology. If this is the case, Comte's conception has not lost relevance. The difference in levels of complexity is still an important issue in any discussion of the ontological dimension of the various sciences.

Comte's differential theory of science inaugurated an original tradition in epistemology, one that can be regarded as specifically French. It started to develop at the end of the nineteenth century, when academic philosophers such as Boutroux began to be interested in Comte's work. Ever since then, French history and philosophy of science have been closely intertwined. This historical epistemology, as it has been termed, replaced the search for logical foundations with a problematic in which processes of concept formation were analyzed as historically and regionally bound. This mode of analysis, represented by Gaston Bachelard and Georges Canguilhem, broke with Comte's theory of knowledge but continued his historical and differential approach. That development was opposed to the logical positivism that had come to dominate the Anglo-American world. The French reception of Kuhn's work, for example, which has astonished foreign observers, can only be understood with reference to the "Comtean tradition " in the sense outlined above.

If Auguste Comte is seen in this way, one cannot accept the nonchalant contempt with which many academics today refer to his work. Yet this is not the whole story. In fact, Comte's theorizing contained a fundamental shortcoming: his objectivism ${ }^{28}$. Comte's approach was confined to a theory about the objects of the various sciences. It gave no real account of the subjects of scientific work and the social practices they involve. For Comte science was an activity of humanity; the only way to explain why certain people discover certain things at a certain time was by referring to his levels of complexity : the human mind necessarily discovered simple

27. See, for example, "Premier aperçu d'un travail sur le gouvernement parlementaire considéré comme régime transitoire", 1817, in op. cit. supra n. 5, p. 68-73.

28. For a general discussion of objectivism, see Pierre Bourdieu, Le Sens pratique, Paris, Éd. de Minuit, 1979. 
phenomena before more complex ones. This is a poor explanation for the actual development of the sciences. By eliminating the scientists from science, Comte eliminated all the problems of interpretation and sociability. Recent work has made it quite clear that these dimensions, related to scientific actors and the positions they occupy in the scientific field, should be included in any adequate theory of science. Yet there is no reason why such a theory should be incompatible with a historical and differential approach such as Comte proposed.

Johan HeIlbron, Université Erasme, Rotterdam. 